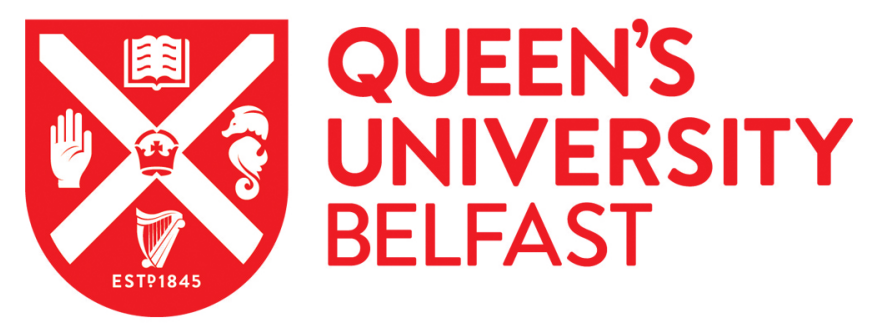

\title{
The Politics of Artistic Identity. The Czech Art World in the 1950s and 1960s
}

Svasek, M. (2001). The Politics of Artistic Identity. The Czech Art World in the 1950s and 1960s. In G. Péteri (Ed.), Intellectual Life and the First Crisis of State Socialism in East Central Europe, 1953-1956 (pp. 133-153). Norwegian University of Science and Technology.

Published in:

Intellectual Life and the First Crisis of State Socialism in East Central Europe, 1953-1956

Queen's University Belfast - Research Portal:

Link to publication record in Queen's University Belfast Research Portal

\section{General rights}

Copyright for the publications made accessible via the Queen's University Belfast Research Portal is retained by the author(s) and / or other copyright owners and it is a condition of accessing these publications that users recognise and abide by the legal requirements associated with these rights.

Take down policy

The Research Portal is Queen's institutional repository that provides access to Queen's research output. Every effort has been made to ensure that content in the Research Portal does not infringe any person's rights, or applicable UK laws. If you discover content in the Research Portal that you believe breaches copyright or violates any law, please contact openaccess@qub.ac.uk. 


\title{
The Politics of Artistic
}

\section{Identity: the Czech Art World}

\section{in the I950s and 1960 s $^{\star}$}

\author{
MARUŠKA SVAŠEK
}

\section{Introduction}

Since the Czech 'revivalist' movement of the last century, Czech art - along with the roles assigned to its artists - has been undergoing a continual process of definition and redefinition. ${ }^{1}$ The question of what constituted and what should constitute Czech artistic identity has often proved politically charged, with artists and art historians on opposing sides attacking each other for their political views. More often than not, debates on the issue have been part and parcel of wider social contexts in which artists and art historians have competed for influential positions and artistic prestige within the art world itself. ${ }^{2}$

This article aims to analyse the power struggle which took place within the Czech art world in the I950s and I960s between orthodox Stalinist art historians and artists and their more liberal (both Communist and non-Communist) colleagues. It focuses in particular on conflicts arising from attempts to define Czech artistic identity and the role of artists. To provide an insight into the complex relationship that existed between the artistic and political aspects of this struggle, the article uses three levels of analysis: the organisational dynamics in the art world, the formation of social groups and hierarchies, and the creation of artistic discourses. On each of the three levels, changes came about which directly influenced the stuggle to define artistic identity and the role of artists in society.

I would like to thank Kathleen Burk, Justin I'Anson-Sparks, Peter Pastor, Gyorgy Péteri and Contemporary European History's anonymous referee for their critical remarks on an earlier version of this paper.

1 Maruška Svašek, 'Styles, Struggles, and Careers. An Ethnography of the Czech Art World, 1948-1992', PhD thesis (University of Amsterdam, 1996); idem, 'The Soviets Remembered: Liberators or Aggressors?', Focaal. Joumal of Anthropology, Vol. 10, no. 25 (1995) 103-24; 'What's [the] Matter? Objects, Materiality, and Interpretability', Etnofoor, Vol. 9, no. 2 (1996), 49-70.

2 Inherent in all artistic discourse is the concept of artistic quality, by which 'good' artists are distinguished from 'bad', and hierarchies of artistic reputation are created. A higher reputation normally brings commercial benefits in the art market and a place in art history. However, the definition of artistic quality is never totally fixed, and art specialists may support conflicting opinions. Defining what is art and what not thus often remains a contentious issue debated by art historians and artists who struggle for the acceptance of their own particular viewpoint. In specific socio-historical contexts the struggle for artistic recognition becomes inseparably linked with political power struggles. 
The article makes use of the terms 'public' and 'hidden' discourse put forward by the anthropologist James Scott. The former refers to people's conformism within an oppressive political system, while the latter refers to their unvoiced criticism and resistance. For Scott, public and hidden behaviour are to be regarded as two poles of a continuum, political changes as moments in which hidden, unvoiced criticism, suddenly becomes public:

$[\mathrm{P}]$ aying close attention to political acts that are disguised or offstage helps us to map a realm of possible dissent. Here, I believe, we will typically find the social and normative basis for practical forms of resistance . . a as well as the values that might, if conditions permitted, sustain more dramatic forms of rebellion. ${ }^{3}$

Scott's perspective helps explain why and how issues of Czech artistic identity and the role of artists were linked to political conflicts within the country and the Eastern bloc as a whole. It also shows just how hidden forms of resistance in the art world could develop into public acts of protest which, given certain developments on the international political stage, could generate domestic political change.

\section{The Czech Avant-Garde: Abstraction and the Link with Western Europe}

To be able to understand the complexities of the situation in the Czech art world in the I950s, it is necessary to look briefly at a number of developments which took place during the first half of the twentieth century. Before the Communist coup in February 1948 (with the exception of the period of occupation during the Second World War), the Czech art world was noted for its organisational, social and discursive pluralism. A wide variety of artistic styles co-existed, ranging from conventional figuration to innovative abstraction. Czech artists had close ties with the West, and a number of them participated in international avant-garde art movements such as Cubism and Surrealism. On occasion, they travelled to Paris, the centre of the innovative avant-garde, where they participated in international exhibitions. In Prague, various art associations such as Mánes and Umělecká Beseda organised exhibitions of avant-garde art and reviewed abstract works in their art journals.

Cubo-Expressionism (a stylistic mixture of Cubism and Expressionism) was defined as a uniquely Czech genre, whereas other Czech art works were predominantly classed as belonging to one or another artistic genre within European art history, meaning the history of High Art (in contrast to that of 'lower' folk art). It would not be too great a generalisation to say that the artists who gained most prestige in the Czech art world during the first half of the twentieth century were those who created international, abstract avant-garde works. The production of innovative styles and experimentation with abstraction were two of the most central aims. Resistance and outsiderism were inherent in the avant-garde tradition. The avant-garde artists defined themselves as 'independent creators' and attacked artistically stifling, bourgeois norms. During the Second World War, when the Nazi occupiers banned their

3 James C. Scott, Domination and the Arts of Resistance: Hidden Transcripts (New Haven/London: Yale University Press, 1990), 20. 
works and labelled them 'Entartete kunst', the artists who continued to produce avant-garde works in secret regarded their activities as acts of political resistance.

\section{Gottwald's 1948 Speech on Art and Culture: Artists as Political Propagandists}

Even though many visual artists (particularly after the betrayal at Munich in 1938 and the liberation by the Red Army in 1945) became members of the Czech Communist Party, they remained artistically orientated towards Western Europe and towards abstraction. ${ }^{4}$ After the Communist coup in February 1948, however, they were forced to adapt to a new political situation. The relatively autonomous, pluralist art world was re-organised into a centralised, politically controlled public institution. With the onset of the Cold War, all official communication with Western art worlds was broken off, and abstraction was redefined as a type of 'bourgeois formalism'.

A few months after the coup the Czechoslovak Communist Party organised the Congress of National Culture (Sjezd národní kultury). During the Congress the President and Party leader, Klement Gottwald, delivered a speech redefining the role of artists and intellectuals in the new 'socialist democracy'. 5 The President announced that, in the present political order, artists and intellectuals would no longer work for élitist groups of successful capitalists (servitude to whom had, in the past, created an illusion of artistic independence and freedom at the expense of the needs of the working classes), but would henceforth make their work accessible to all people in society. ${ }^{6}$ Gottwald made his point with a series of rhetorical questions.

4 For a more elaborate analysis of the period 1938-48, cf. Svašek, 'Styles, Struggles and Careers', $26-33$.

Klement Gottwald, 'Projev Klementa Gottwalda na Sjezdu Národní Kultury I948', Výtvamé Uméní, Vol. I, no. I (1950), 4; Vilém Jüza, 'Smutná léta padesátá. Druhá avantgarda', in Jiň Vykoukal (ed.), Záznam Nejrozmanitéjsích Faktoru. Ćeské Maliŕství 2. Poloviny 2o. století ze Sbírek Galení (Prague: Národní Galerie, 1993), 27.

6 The idea of artists and intellectuals being a closed élitist group, mistakenly considering itself 'free and independent', was not an idea bandied about within the Eastern Bloc alone. It was also taken up and further developed by Western European socialist scholars. The topic was heatedly debated in the interwar period in Britain and France and during the immediate post-war years throughout Europe. Various Western social scientists, historians, literary critics and writers developed theories in which they viewed the role of art in modern capitalist societies as an instrument of class distinction. See further, Theodor Adorno, Introduction to the Sociology of Music (New York: Seabury Press, 1976); Walter Benjamin, Understanding Brecht (London: New Left Books, 1973); Pierre Bourdieu, 'Symbolic Power', Critique of Anthropology, Vol. 4, no. 13-14 (1979), 77-85; Distintion. A Social Critique of the Judgement of Taste (London: Routledge and Kegan Paul, 1984); Bertold Brecht, 'A Short Organum for the Theatre', in John Willet (ed.), Brecht on Theatre. The Development of an Aesthetic (London: Eyre Methuen, I964), 179-205; Terry Eagleton, Criticism and Ideology (London: New Left Books, 1976); Nicos Hadjinicolaou, An History and Class Struggle (London: Pluto, I978); Francis Haskell, Rediscoveries in Art: Some Aspects of Taste, Fashion and Collecting in England and France (Oxford: Phaidon, 1976); Arnold Hauser, The Social History of An (London: Routledge and Kegan Paul, 1968); Pauline Johnson, Marxist Aesthetics. The Foundation within Everyday Life for an Emancipated Consciousness (London: Routledge and Kegan Paul, 1984); Herbert Marcuse, One Dimensional Man (London: Routledge and Kegan Paul, 1964); The Aesthetic Dimension: Towards a Critique of Marxist Aesthetics (Boston: Beacon Press, 1978). 
From whom [must artists and intellectuals] withdraw today? From whom must they protect their so-called 'inner freedom' and 'independence'? From the people? . . . . Today the exact opposite is necessary - the broadest genuine co-operation and honest service to the whole. They must not be afraid to meet other levels of society, and must not be afraid to go out amongst the people and make them conscious. ${ }^{7}$

Artists were to serve the interests of the people and become integrated into a single, unified society. They would, so they were told, only gain respect by expressing shared, far more 'preferable', socialist ideals. The President criticised intellectual and artistic élitism: 'I really do not know why higher culture should only delight tens of hundreds of exclusive individuals, when it could stimulate hundreds of thousands and millions on the march to the great ideals of the humanities'. 8

Gottwald gave clear directives as to how artists and intellectuals should behave. He called upon them to accept the newly formed Communist cadres, in spite of their lack of education, because they would play a crucial role in the nationalisation and popularisation of culture. These measures were intended to counter the control which the international bourgeoisie had exercised over culture, knowledge and the arts before February 1948. In other words, the Communists claimed for themselves the right to shape and control public, artistic and intellectual discourse and practice.

Gottwald argued that art and culture would serve a national purpose. 'In the people's democracy, culture is not and will never be a Cinderella, as it was under capitalism, but will be an important source of national power and will be a national asset which they [intellectuals and artists] must nurture and support' (emphasis added). ${ }^{9}$ In Stalinist discourse, art and culture were thus interpreted as public property which should be used to propagate Communist values. National struggles were redefined as essential parts of the (more fundamental and important) intemational struggle against capitalism and 'bourgeois élitism'. The fight for a Communist future by individual People's Democracies was first and foremost defined as a collective struggle.

Gottwald assured his audience several times that no one would suffer any loss of status in the new order, because they would be given the important task of protecting and giving form to the new socialist culture.

It is wrong to be anxious about the destiny of intellectuals and culture in the people's democracy .... I repeat again: in our people's democratic state, in our march towards socialism, no kind of degradation will be suffered whatsoever by our intellectuals. Exactly the opposite will be the case: their task will grow, [and] will not be subject to the grace and disgrace of capitalist despotism . . . . They will co-operate in the contribution made by all people to the prosperity of the whole. ${ }^{10}$

In contrast to these words of reassurance, he warned his audience not to distrust or fear the new political order. Artists and intellectuals who did not accept Communist

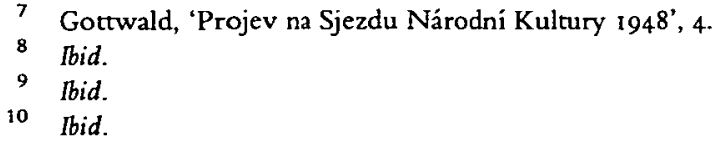


ideology posed a threat, he claimed, because their fear was 'causing unrest in the country', and was creating 'a gulf between the worker and the intellect' ${ }^{11}$

The demonising of 'enemies' within a country's national borders is a common element of political discourse. ${ }^{12}$ The Czechoslovak Communists used the notion of political enemies as a negative myth, which contrasted with the positive myth of socialist man. After Gottwald's claim that they would 'hinder the country's development', all kinds of negative characteristics were ascribed to intellectuals and artists who were unwilling to accept the new 'order'. ${ }^{13} \mathrm{He}$ did not mince words when describing what would happen to those who did not co-operate:

In February [the date of the Communist take-over], we did not sweep the pieces of these malevolent thoughts away with a feather duster, but with an iron broom. We will likewise sweep away the heritage it has left behind, we will sweep away all deceitful opinions that create a breakdown between the working hand and the mind, whether they are the product of malintent or unconsciously made. ${ }^{14}$

\section{Official Art History in the Context of the Cold War}

After the coup of 1948 , Czechoslovak official artistic discourse became highly influenced by Cold War rhetoric. ${ }^{15}$ Artists whose work was considered important in pre-I 948 art history, were classified as either Western-style reactionary enemies or progressive friends. It was claimed that the former produced works which mystified reality while the latter sought to elucidate reality and make people politically conscious. ${ }^{16}$

In Czechoslovakia, artists from East and West who had made art works which could be appropriated to fit Communist political discourse were positively reviewed in the art journal The Visual Arts (Výtvarné Uméní), established in I95o. The critic Vladimir Solta so enthusiastically discussed the works of nineteenth-century French, Russian and Czech Realists that the bygone artists themselves seemed to approve of current Eastern bloc politics. The French painters Honoré Daumier and Gustav Courbet were praised for the support they had given to 'the expansion of the proletarian movement', and the members of the Russian art group The Wanderers (Pérédvižníku) were praised for taking their inspiration from the common

\footnotetext{
11 Ibid.

12 See Raphael Samuel and Paul Thompson (eds.), The Myths We Live By (London and New York: Routledge, I990), s.

13 Gottwald, 'Projev na Sjezdu Národní Kultury 1948', 4.

14 Ibid.

15 See Christine Lindey, An in the Cold War. From Madivostok to Kalamazoo, 1945-1962 (New York: New Amsterdam Books, 1990), 8.

16 According to Lindey, the demonising and idealising of two opposing groups of artists during the Cold War should be set against the backdrop of the Second World War, during which people had become used to thinking in terms of allies and enemies. She argues that, after 1945, "it was easy for people to substitute the Red Menace or the Capitalist Devil for the Nazi Demon'. Ant in the Cold War, 8. In the West, the media similarly propagated an extremely simplified and negative mythical image of their Soviet counterparts. H. L. Nieburg, Culture Storm: Politics and the Ritual Order (New York: St Martin's Press, 1973), 204.
} 
people. ${ }^{17}$ In Czech art history, Josef Mánes, Mikoláš Aleš and Josef Václav Myslbek, were considered good examples of progressive art. Under the Hapsburg Empire they had been active in the nationalist movement, producing art works which were inspired by Czech folk culture. This made their work ideologically sound. Solta invoked memories of the Second World War and the struggle against fascism to prove his point. The following extract was written about the work of the artist Mikoláš Aleš.

Thousands of our nation's members will acknowledge that Aleš's monumental designs, and his illustrations in books and school textbooks, taught them to love the Czech people, the Czech countryside and Czech history. Even during the reign of fascist terror they inspired national pride and consciousness, and convinced our generation of the future power and glory of our nation. ${ }^{18}$

Standing in direct opposition to progressive art was the cosmopolitan art of the enemy, which included all non-figurative styles. Impressionists, Cubists and Surrealists, Šolta argued, had all sought to 'construct an art outside reality, to deprive it of its effect as an instrument for enhancing knowledge and transforming reality'. He accused its proponents of 'covering up class conflicts' and of 'turning away from reality'. ${ }^{19}$ All propagators of idealist aesthetics, he argued, were agents of the imperialist capitalist bloc led by the United States.

Given our present circumstances, the 'ideologists' of cosmopolitan art are propagators of the most reactionary obscurantism, and through their activities they aim to break the consciousness and power of the working masses, and thus prepare the ground for an invasion by the usurpers of global power, the imperialists from Wall Street. ${ }^{20}$

Šolta did not deny the historical reality of a strong Czech avant-garde, but reinterpreted it to his own ends, praising artists who had 'kept on working in a realist vein even when decadent cosmopolitan art had become the fashion'. ${ }^{21}$ At the same time he was keen to cite examples of artists who, as it were, had been reconverted from non-figuration to realism, and who were therefore especially worthy of artistic respect. At the time the article was published this was something of an olive branch offered to those readers with an avant-garde past. They, too, would be given a chance to build a new artistic career in the new Communist society.

17 The Wanderers were inspired by works of Chernyshevsky such as The Aesthetic Relations of Art and Reality (1 855) and What is to be Done? ( 1864 ). Chernyshevsky advocated an art that would not limit itself to the beautiful but which would embrace the whole of reality. David Elliot, New Worlds. Russian Ant and Society 1900-1937 (New York: Rizzoli, 1986), 8.

18 Vladimír Šolta, 'K některým otázkám socialistického realismu ve výtvarném umeni', Výtvamé uméní, Vol. I, no. 3 (1950), 1 ro.

19 lbid.

20 Ibid.

21 Ibid., I I 7-I8. Šolta referred to Antonín Slavíček and Max Švabinsky as exemplars. Slaviček (1870-1910) mainly painted landscapes. Eva Reithartová, 'Slavíček, Antonín', in Emanuel Poche (ed.), Encyklopedie ćeského výtvamého uméní (Prague: Ćeskoslovak Academy of Science, 1975), 464. Švabinsky (1873-1962) was known for his historical paintings. Ludvík Hlaváček, 'Skupiny tvürcích umělcủ', in Emanuel Poche (ed.), Encyklopedie českého výtvamého uméní (Prague: Českoslovak Academy of Science, I975), 519. 


\section{The Division between Official and Unofficial Artistic Discourse}

In this new political environment, artists and art historians who had earlier defined themselves as 'non-political professional experts' or 'independent critics' (for example, of bourgeois norms or the Nazi occupation) were expected to redefine themselves as 'propagandists of socialist [i.e. Stalinist] ideas'. If they wanted to gain prestige in the context of the re-organised art world, they had no option other than to conform to the official notion of artistic identity. To those who supported the ideals of state socialism and who worked in figurative styles this was not a problem. They believed that the political turn-around would improve working conditions for them, and that Stalinism would bring about a better future for all Czechoslovak citizens. Partly or wholly convinced of this, they were ready to use their figurative style for the propagation of socialist values. The journal The Visual Arts introduced them to Soviet Socialist Realist art and other ideologically correct works. Appendix I shows that in I950, 43.5 per cent of the reviewed art works were created by foreign artists from Eastern bloc countries, and ten per cent by 'progressive' colleagues from the West.

Figurative artists benefited from the political situation precisely because they were able to capitalise on their past artistic status. Almost overnight they were officially valued as prominent and important representatives of Czech art. Those interested in organisational matters gained central positions in the newly established centralised Union of Czech and Slovak Artists, and helped create official Stalinist artistic discourse.

In contrast, abstract avant-garde artists found themselves in an unenviable position. Their (neo)Cubist and (neo)Surrealist works were no longer allowed to appear in public, and were defined as 'formalist' representations which mystified reality. The relatively autonomous art associations and art groups which had earlier exhibited avant-garde art were banned. All artists (who wanted to continue to work as artists) had to register as members of the Communist Art Union. Some of them rejected their official role as political propagandists and, in secret, continued to produce works which were politically, and therefore artistically, unacceptable. As a result, they were forced to work outside the official art scene. ${ }^{22}$

In the course of the I950s a new generation of young artists, trained under Stalinism, began to make their way into the art world. Most of them accepted dominant aesthetic norms and worked according to the Socialist Realist method. For a limited number of young graduates the question of whether or not to participate in the official art world was more vexing. They had found their education limiting and had drawn no real inspiration from the works created by their teachers. At the same time, the lack of an alternative, resulting from the imposition of ideological safeguards on the official art world, offered them little hope of remedying the situation. Censorship and the fear of being labelled bourgeois

22 See Vlastimil Tetiva, Ćeské malírství a sochaŕství 2. poloviny 20. stol (Hluboká nad Vltavou: Alšova jihočeská galerie, 1991), 53 . 
traitors deterred them from seeking out information about certain artists and artistic styles. Adriena Šmotová (b. 1926), who studied at the School of Applied Arts from I945 to I950, remembered how she had 'smuggled' a book about the work of Paul Cézanne out of the school library. At times she herself had been accused of working in a bourgeois style. She recounted:

If I wanted to borrow a book about Cézanne from the school library, I had to carry it out under my coat so that nobody would see it. It was absolutely absurd. Once I made a sketch for a mosaic, and they wagged their finger at me and said that it was Impressionism!

Artists such as Šimotová began to form small unofficial art groups. 'Offstage' they met each other and discussed the pre-war Czech avant-garde and their own 'formalist' art works. In addition, they organised clandestine group exhibitions in their studios, ${ }^{23}$ and secretly contacted older artists who had belonged to the avantgarde, such as the Surrealist Karel Teige (1900-50). The sculptor Hugo Demartini (b. I93 I) noted: 'We were lucky that we succeeded in having contact with some older artists who had known it [avant-garde art] and who were rooted in it. There were only a few artists whom we respected and found interesting.' Young artists received information about the pre-Communist pluralist art world and a variety of artistic styles not only through the stories and works of older non-conformist artists but also by reading old journals and art books. Although avant-garde works had been removed from museums and galleries, some of the pre-1948 art journals and art historical publications were still available from public libraries and private individuals.

The Stalinist re-organisation of the art world generated, however, a division between public official and clandestine unofficial artistic discourse. Before the coup, the art world had been divided into groups of artists who belonged to the artistic establishment and groups of those who were not (yet) established. This distinction differed in some important respects from the post-I 948 distinction between official and unofficial social spheres. Before 1948 , artists' success had mainly depended on favourable reception of their works by prominent critics, dealers and collectors. Artists who did not belong to any established association were free to form their own art groups, and were allowed to organise exhibitions and discuss their works in public. Their personal attitude towards politics did not necessarily influence the critical reception of their works. In contrast, under Stalinism, open competition outside the official organisational structures was forbidden, and the primary criterion for success was political conformity. The centralisation of the art world and the system of censorship ensured that all art works which appeared in public were ideologically correct. This forced artists who refused to act as political propagandists to hold unofficial artistic discourses in secret. Paradoxically, the producers of

23 Scott noted that, in general, people in situations of extreme oppression only dare to voice alternative opinions if they possess a 'sequestered social site where the control, surveillance, and repression of the dominant are least able to reach', and which must be 'composed entirely of close confidants who share similar expressions of domination'. Scott, Domination and the Arts of Resistance, 120. 
unofficial art were often indirectly integrated into the official organisational structure through compulsory Art Union membership, which was required of all practising artists.

\section{The Formation of Unofficial Art Groups}

Inspired by non-realist avant-garde styles, young artists who did not approve of the repressive Communist art policy set about creating works which were not acceptable to the Art Union employees who organised exhibitions. The twin sisters Květa and Jitka Válová (b. 1922) graduated from the School of Applied Arts in r95o and I95I. When asked to describe the atmosphere in the art world after their graduation, they responded:

KV: It was very bad.

JV: We couldn't exhibit because they wouldn't let us.

MS: Because you created a different style of art?

$\mathrm{KV}$ : Yes, we made different things, we didn't work in a realistic vein.

MS: Did you try to exhibit?

KV: No, it was clear [that we couldn't]. There were still art associations up until 1950, but even when we took things along they never showed them at any of the exhibitions. There was no point in trying.

MS: Were there a lot of young artists who had similar difficulties?

JV: Yes, a lot.

KV: Those who stood for something. The rest just licked arses and copied nature. They weren't artists.

Those who wanted to discuss and exhibit their works were forced to create their own clandestine networks and, as a result, more than ten unofficial art groups were established between 1954 and 1960. The members of the groups held exhibitions and meetings in the privacy of their homes and studios. The groups which became best known were Trasa, Máj, ${ }^{24}$ Radar, ${ }^{25}$ Skupina $58,{ }^{26}$ MS 6I, Etapa, UB I $2,{ }^{27}$ Šmidrová, Experiment and Proměna.

Květa and Jitka Válová were members of the group Route (Trasa): ${ }^{28}$

24 Members included J. Balcar, A. Bělocvětov, V. Beneš, B. Čermáková, L. Dydek, L. Fára, R. Fremund, M. Hájek, D. Hendrychová, F. Caun, M. Chlupáč, J. Kolínská, J. Martin, M. Martinová, Neprakta, J. Winter, V. Nolč, D. Nováková, Z. Palcr, R. Piesen, J. Rathouský, J. Skrivánek, M. Vystrčil and K. Vysušil.

${ }_{25}$ J. Bartoš, V. Bláha, D. Foll, F. Gross, F. Hudeček, J. Chadima, V. Kovařik and O. Synaček.

26 J. Broż, J. Grus, K. Hladik, S. Ježek, M. Jirava, J. Kodet, J. Liesler, J. Malejovsky̌, V. V. Novák, J. Otčenášek, J. Smetana, A. Sopr, V. Tittlebach, R. Wiesner and V. Žalud.

${ }^{27}$ V. Boštík, F. Burant, V. Janoušek, V. Janoušková, J. John, S. Kolíbal, A. Kučerová, J. Mrázek, D. Mrázková, V. Prachatická, O. Smutný, A. Simotová and A. Vitik.

28 Members included the painters Eva Burešová, Vèra Harmanská, Vladimúr Jarcovják, Čestmir Kafka, Dalibor Matouš, V. Menčík, Karel Vaca, Jitka Válová and Kvéta Válová and the sculptors Zdenek Fibichová, Eva Kmentová, Václav Preclík, Zdeněk Šimak and Olbram Zoubek. 
KV: We established the group Route in 1954. The majority of us were Emil Filla's (a prominent Cubist painter) [ex]students, but a year later some of Vágner's [ex]students also joined us. Altogether there were about thirteen members. We started having meetings, showing each other what we were doing, and discussing it.

MS: Did you meet often?

$\mathrm{KV}$ : Almost every week.

MS: In a studio, or in a pub?

$\mathrm{KV}$ : Always in a studio. We always took our works with us to chat about.

The unofficial activities of illegal art groups automatically assumed political significance. As Jeffrey Goldfarb said in his analysis of political domination and resistance in Polish theatre, 'when opposition politics is not possible, politics through aesthetics keeps social alternatives alive'. ${ }^{29}$ The very fact that a number of artists offered alternative views, albeit in secret and on a small scale, was highly significant. They formed a social space for indirect but active opposition to the Stalinist regime, proving that it was still possible to hold and express views which differed from the official doctrines put forward by the Party.

Initially Route members painted or created sculptures of everyday objects and situations in an expressive, dramatic style. In the late I950s, they became interested in existentialist philosophy. ${ }^{30}$ From the perspective of Socialist Realist aesthetics the existentialist world view was intolerable. The emphasis on the misery of human existence, inevitable suffering and the lack of hope for change, conflicted with the optimistic message of Socialist Realist works. In the Czech Stalinist context, existentialist art works referred not only to past aggression but also to the oppression experienced throughout the I950s. When asked what existentialism meant in the context of the I950s, Jitka Válova referred to the isolated position of the nonconformist artists: 'People were more introverted. They had no alternative because you couldn't communicate with the outside world. Well, there was one alternative, but fuck that!'

The formation of groups outside the official structures did have some political efficacy within the art world, in as much as it proved that the leaders of the Art Union lacked the power to dominate all artistic discourse and practice. The effect, however, was mostly one of raising morale. The secret activities psychologically supported unofficial artists (who would otherwise have worked in isolation) by convincing them that they were not alone in their fight. Through their activities they created an area of potential political power which could be harnessed and put

29 Jeffrey Goldfarb, On Cultural Freedom. An Exploration of Public Life in Poland and America (Chicago: University of Chicago Press, 1982), 98.

30 Defined as '[a] loose title for various philosophies that emphasise certain common themes: the individual, the experience of choice, and the absence of rational understanding of the universe with a consequent dread or sense of absurdity in human life. The combination suggests an emotional tone or mood rather than a set of deductively related theses, and existentialism attained its zenith in Europe following the disenchantments of the Second World War.' Simon Blackbum, The Oxford Dictionary of Philosophy (Oxford: Oxford University Press, 1994), I29-30. 
into action in the interest of autonomising the art world whenever the political climate allowed it.

\section{Open Criticism in the Art Union}

By the mid-1950s, an increasing number of artists and art historians who had supported Communist ideals in 1948 had become disappointed with the effect of official art policy. As a result, some began to express their doubts about the rigidity of Socialist Realism. Respected and influential members of the Art Union, such as the art historian Jaromir Neumann, began openly to question the value of the method in 1955. The art historian Jiŕ Kotalík (1920-96), who was head of the editorial board of the official art journal The Visual Arts between I953 and I954, argued that he had never believed in it anyway.

The third major exhibition of Czechoslovak art, organised by the Art Union at the Prague Riding School (Jizdárna) in I955, triggered the art historians' critical reaction. The works exhibited, all of which were examples of Socialist Realism, highlighted the 'rigid standardisation' which had been enforced. ${ }^{31}$ After visiting the exhibition, Neumann and other respected art historians and critics initiated a debate about the works' poor level of artistic quality and through their critical artistic discourse, indirectly attacked the inflexible political system. This was rather risky because the deaths of Stalin and Gottwald in 1953 had not yet resulted in a less rigid form of Stalinism.

Alarmed by the debate, and in an attempt to pre-empt it, the Union's Central Committee decided to organise a conference to discuss its regulatory role. For the first time in its history the organisation was openly criticised by its own members. The art historian Miroslav Lamač, for example, attacked the Union for its over-insistence on the use of particular themes. At two other conferences about art criticism in the same year, similar criticisms were made. Some critics claimed that the art historians who worked for the Union lacked a scientific approach. Jaromir Neumann, a former advocate of Socialist Realism, stated that it was necessary to return to the method of historical comparison. ${ }^{32}$ By positively (re-)evaluating 'objective' art historical methods which had been developed before 1948 , the art historians claimed art history as a science that was not, nor should be, inseparable from politics.

In a reaction to the protests by respected art historians, less influential artists also dared to voice objections which they had previously only discussed in secret. Young artists in particular demanded better representation in the Union and travel grants for visits to East and West European countries. In addition, they demanded their own galleries and the right to establish art groups outside the Union. They claimed that the Union was too bureaucratic, politicised and impersonal. ${ }^{33}$

31 Jủza, 'Smutná léta padesátá', 30.

32 lbid.

33 One of the artists I spoke with, who was a member of one of the unofficial art groups in the late 1950s, told me that small art groups were a necessary counter to the overwhelming dominance of the 
In Scott's terminology, one could say that, six years after the Communist coup, the proponents of official art policy who operated 'on stage' began to split into groups. One remained dogmatic and political, and ignored the stiffling effects of Stalinist art policy. The other became increasingly critical and self-reflective, and tried to introduce a policy which was less prescriptive. Their self-criticism stimulated less powerful Union members to make public their own hidden criticism.

A number of Union officials were willing to introduce organisational reforms and to remove some of the restrictions imposed by the Socialist Realist method, which would allow illegal art groups to exhibit their works publicly. Without openly admitting any error, they acknowledged that artists should have (at least to some degree) artistic freedom. Their willingness to change can be explained by their own dissatisfaction with some of the (unforeseen) consequences of their own Stalinist art policy. Firstly, the monolithic Union did not satisfy the seemingly natural need of artists to form smaller groups. Secondly, basing the judgement of artistic quality on political criteria had resulted in the endless repetition of a limited number of standardised artistic themes.

Even though some Union officials were, as a result, willing to introduce changes within the Union, their attempts were thwarted by hardliners who continued to support Stalinist policies, and who feared they would lose their jobs if the Union were liberalised. They therefore continued to frustrate all attempts to reform the system. ${ }^{34}$ More minor re-organisation was also vetoed by Party leaders who similarly disapproved of change. Despite Stalin's and Gottwald's deaths in 1953, the Czechoslovak government remained dogmatic. Decentralisation directly contradicted the Stalinist model of society, and therefore would, it was felt, undermine the authority of the Party.

\section{The Increased Tolerance Exercised by the Editors of the Art Magazine The Visual Arts}

Even though attempts to introduce organisational reform within the Union in I955 had proved unsuccessful, the editors of the art magazine The Visual Arts began to take a more tolerant line. More liberal art historians thus increased their influence over official art policy. It was clearly easier gradually to widen the political boundaries of artistic discourse than to push through far-reaching organisational reform. The increasing tolerance of the journal must be placed in the context of international political developments. In 1956, Stalin's successor, Nikita Khrushchev, announced a new policy of de-Stalinisation in which Stalin's dogmatic policies were heavily criticised. Even though the Czechoslovak government, headed by Antonín Zápotocký, refused to take up the Soviet political line, artists and art

Union. The illegal groups offered artists the possibility of meeting colleagues with similar interests, with whom they could discuss both art in general and their own work. However, they also felt the need to exhibit their work before a wider public, and wished to use the official network of galleries and museums to do so.

34 Jủza, 'Smutná léta padesátá', 31 
historians who heard rumours about the Soviet developments dared to resist in more visible ways.

Between 1956 and 1960 the editors progressively lifted the ban on Czech and Western 'bourgeois' avant-garde art. In I955, the journal, for the first time since its establishment, included more reproductions of works by Western than by Eastern bloc artists (see Appendix r). Eleven per cent were by the former, with only eight per cent by the latter. By 1956 this difference had become even more noticeable (34.6 and 4.2 per cent).

An early attempt by the editors to stretch the limits of censorship clearly came in I956 with the publication of the article 'Modern Art', in which the art historian Miroslav Lamač reviewed the work of a number of Western avant-garde artists. From the viewpoint of Socialist Realist aesthetics, the works which illustrated the article were not particularly shocking. All but one were figurative depictions of politically neutral topics or social themes. ${ }^{35}$ The one exception was a study for the painting Guernica, by Pablo Picasso. Though the work was Cubist, its warning against the terror of fascism was a sufficiently acceptable theme in Communist discourse.

More daring than the reproductions, however, was Lamač's own attack on ideas fundamental to Socialist Realism. In Socialist Realist aesthetics the 'pejorative' equation of avant-garde art with formalism, and the incompatibility of Realism and Abstractionism, were fundamental. Lamač however rejected these basic assumptions:

the equation of modernism with formalism has been one of the greatest mistakes of the past .... Artists [such as Picasso, Matisse or Bonnard], who so passionately researched man, who so much enriched our artistic knowledge of reality, and who discovered so many new expressive possibilities, cannot be formalist. ${ }^{36}$

Accompanying Lamač's text, the reproductions of Western works of art were intended to challenge the dogmatic Stalinist view of art. In the context of earlier debates held by the Union it heralded a potential political change.

The publication of Lamač's article demonstrated that the editors of The Visual Arts were ready to discard, or at least defy, Cold War rhetoric, which had divided the world into the categories of 'friendly realists' and 'hostile formalists'. During the

35 Some of the artists reviewed, such as Gustav Courbet and Théodore Géricault, had already been accepted as socially conscious realists, and their work had already been reviewed. In Lamač's article they were represented by paintings with social themes, such as a beggar and a woman in a kitchen. Other painters discussed by Lamač, such as Manet, Dégas, Renoir and van Gogh, now appeared for the first time in the magazine. However, as had been the case with Picasso in 1953, none of their more abstract works were shown. Instead, realist paintings that had a social or relatively neutral content served as illustrations. Van Gogh, for example, was represented by a painting of agricultural labourers. ToulouseLautrec's work showed people in a bar, Renoir's people in a street, Pierre Bonnard's people in a garden, Manet's a woman applying her make-up; and Dégas was represented by three of his nudes, a woman ironing and a dancer. The most avant-garde artists Lamač wrote about were Picasso and Matisse. The reproduction of Matisse's painting depicted a woman and a child.

36 Miroslav Lamač, 'Modemi uméni I', Výtvamé uméní, Vol. I7, no. S (I956), 2 I 2. In the same issue Picasso was quoted as attacking the idea that Realism and Abstractionism were incompatible artistic categories. The quote was taken from his interview with Christian Zervos, originally published in Picasso 1930-35 (ed. Cahiers d'art). Picasso's and Lamač's statements reinforced each other. 
late I950s, the editors gradually distanced themselves from this dogmatic political line. The Socialist Realist view of art was no longer presented as the indisputable truth, but came to be regarded as yet another artistic movement that should also be open to criticism. In 1957, the magazine published an article by Jindrich Chalupecký which criticised pre-formulated artistic programmes. He claimed that over-defined procedures and methods made artistic creation impossible. ${ }^{37}$ In the same year, in an extended article, the art historian Jiri Padrta introduced readers to a variety of twentieth-century modernist styles. ${ }^{38} \mathrm{He}$ claimed that knowledge about the historical development of abstract art was a necessary prerequisite for any serious criticism on the subject. By presenting the history of 'the range of different branches of its aesthetics' and 'its historical origins, development, and the way it has been recorded in both available and less accessible literature', he aimed to help readers formulate 'their own opinions and critical judgement'. ${ }^{39}$ By accepting abstractionism as a historical process, Padrta deconstructed the Cold War notion of abstract art as a 'timeless mythical entity' (the art of the arch-enemy), and redefined it as a series of events and processes which could only be understood in their historical context.

In his introduction to the history of abstract art, Padrta dealt with Cubism, Futurism, Dadaism, Surrealism, Fauvism, Expressionism, Concrete Art, Abstract Impressionism, Neoplasticism and Suprematism, and discussed art groups such as De Stijl and Bauhaus. The critic was careful, however, not to express his personal opinion about works by specific artists. He argued that abstract art was a relatively recent development which therefore made any sound judgement difficult. Padrta's cautious attitude can be explained by the fact that, even though increasing tolerance was shown towards Western art within the Union, the official political line was still Stalinist. Padrta, therefore, strategically quoted Western critics while making sure he was not seen to be agreeing or disagreeing with any of them.

One of the critics Padrta quoted was the Frenchman Michel Seuphor, who had written the book l'Art Abstrait. Seuphor's view of art was diametrically opposed to doctrinaire Stalinist aesthetics. According to him art was primarily a personal, inner process.

For abstract artists it is enough to discover oneself. To discover oneself means to find. That is in reality the utmost requirement .... A genuine artist does not imitate anything. He manifests that incommunicable world which is inside himself, which is him, and which he must externally recreate. ${ }^{40}$

Padrta also noted that Seuphor approved of originality and criticised repetition. In the context of the discussion about the routine production of Socialist Realist

37 Jindřich Chalupecký, 'Uměni a skutečnost', Výtvamé uméní, Vol. i 8 (I957), i 57.

38 Jiř Padrta, 'Umèni nezobrazujici a neobjektivní, jeho počátky a vývoj I', Výtvamé uméní, Vol. I 8, no. 4 (1957), I 74-8I; 'Uměni nezobrazujici a neobjektivni, jeho počátky a vývoj 2.' Výtvamé umění, Vol. I 8, no. 5 (1957), $214-21$.

39 Padrta, 'Uméní nezobrazujici a neobjektivní, jeho počátky a vývoj I', 174.

40 Seuphor, quoted by Padrta, ibid., 181 . 
themes, Padrta's decision to quote Seuphor was a clear challenge to the hardline members of the Union.

For artists who had been unable to obtain information about current Western abstract art due to political censorship, the article contained invaluable material. It was illustrated with forty-nine reproductions of abstract works produced between I9IO and 1957 by a varied group of artists, such as the Russian avant-garde painter Vasilij Kandinsky, the Dutch geometric artist Piet Mondrian, the German Abstract Expressionist Hans Hartung, the French Expressionist Jean Dubuffet and the American Abstract Expressionist Jackson Pollock. ${ }^{41}$ The inclusion of American artists was not just a sign that Padrta wished to break with the idea that the American art world was a 'dangerous bourgeois realm', but also a reflection of the fact that, after the Second World War, the centre of artistic innovation had moved from Paris to New York. ${ }^{42}$

One of the works accompanying the article was a painting by František Kupka, a former representative of Czech Cubism who lived in Paris. It was the first time that Kupka's work had been reviewed in the Communist art magazine. Padrta described his stylistic development as a Cubist during the first decades of the century, and defined his position within a group of other, mostly Western European, artists. The painting reproduced in the magazine was a recent work from 1957 , entitled Two Blues (Dvé Modrê). It was a purely abstract composition showing two geometric forms. The painting, displayed together with a series of works by Western artists, proved that post-1948 non-figurative styles had been developed not only by Western but also by Czech artists. By including Kupka's painting, Padrta broke with the Cold War image of a divided art history in which abstract Czech emigre artists in the West were traitors who had lost their right to a place in Eastern European art history.

The articles by Lamač, Chalupecký and Padrta marked the beginning of a period of liberalisation in the official art world. It was a period in which Czech art was again criticised in the context of Western art history, and art theory in general was discussed openly. In addition, they symbolised an end to a period in which official artistic and political discourse had been superimposed upon each other, and the beginning of a process in which artists and art historians would regain a degree of professional autonomy. It should, however, be emphasised that this process took place at a time when, outside the art world, the political scene was still dominated by

41 The first part of the essay was accompanied by twenty-three reproductions of works by Vasilij Kandinsky (3), Joan Miró (2), Hans Arp (1), Willi Baumeister (1), Hans Hartung (1), Marcel Duchamp (I), Robert Delaunay (2), Franz Marc (I), Piet Mondrian (2), Fernand Léger (I), Umberto Boccioni (I), Alberto Magnelli (2), Giacomo Balla (I), Auguste Herbin (I) and František Kupka (I). The second part of the essay, published in the next issue (no. S), contained twenty-six reproductions of paintings by Piet Mondrian (I), Emilio Vedova (I), Roger Bissiere (I), Enst Wilhelm Nay (2), Jean Bazaine (I), (Otto) Wols (I), Mark Tobey (I), Georges Mathieu (I), Hans Hartung (I), Dieira da Silva (I), Geer van de Velde (I), Jackson Pollock (I), Alfred Manessier (I), Boris Lanskoy (I), Georg Meistermann (I), Fritz Winter (I), Maurice Esteve (I), Bram van Velde (I), Gustave Singier (I), Renato Birolli (I), Jean Atlan (1), Gérard Scheider (I), Jean Dubuffet ( 1 ), Pierre Soulae ( 1 ) and Alfred Manessier ( 1 ).

42 See Robert Hughes, The Shock of the New, rev. ed. (New York: Knopf, 1991), 255. 
hard-line Stalinist policies that, in response to the uprising in Hungary in 1956, had become even more entrenched.

\section{A Changing Exhibition Policy: Socialist Realism and Avant-Garde Art as Sources of National Pride}

Whereas in 1956 , de-Stalinisation programmes along the lines of that in the Soviet Union were implemented in Poland and Hungary, no such reforms were introduced in Czechoslovakia. ${ }^{43}$ In the Czech art world however, there were signs that political change was none the less filtering through. Not only did The Visual Arts continue its increasingly tolerant line, but the Art Union's policy on exhibiting art also changed. This policy was characterised by a twin-track approach. On the one hand, Stalinist exhibition organisers continued to hold exhibitions of Socialist Realist works which identified artists as political propagandists and emphasised the links between Czechoslovak and Soviet culture. On the other, the reformist Communist exhibitions' organisers arranged Czech Cubist and Surrealist exhibitions which identified artists as 'free, autonomous creators', and highlighted the unique characteristics of Czech culture. The latter approach was part of what might be termed the deSovietisation of Czechoslovak nationalist discourse.

In 1957, for the first time since the Communist take-over of 1948, the works of the Czech Modernist avant-garde were publicly exhibited. The art historians Lamač, Padrta and Tomeš organised an exhibition in the House of Art (Dúm Umění) in Brno, the capital of Moravia, which was entitled 'The Founders of Modern Czech Art' ('Zakladatelé moderního českého uměni'). The exhibition was intended 'to show young artists, who often referred to (Bohumil) Kubišta, (Emil) Filla, (Václav) Špala, (Josef) Čapek and others, just how to use these names in a correct and responsible way'. ${ }^{44}$ The exhibition organisers attempted to bridge the gap between the youngest generation of artists and art historians and the Czech avant-garde. The former were given the opportunity to study at close quarters the technique and colours of works which they had only ever seen as reproductions, and the latter were encouraged to expand the collections of the Regional Art Galleries to include Cubist and Surrealist works. To the delight of liberals, Party officials deliberately turned a blind eye to the exhibition, which was also shown in

43 The lack of political reform in Czechoslovakia can be explained by a number of reasons. The Czechoslovak economy had not been as drastically affected by Stalinist policies as had the economies of other Eastern bloc countries, and consequently economic pressure for reform was not as great. The majority of intellectuals had remained loyal to the Party and, as a result of the purges and strict political control, those not loyal to the Party had been given no chance to organise themselves. Ethnic and historical differences between Czechs and Slovaks might also have been a factor involved or exploited in hindering the development of any unified opposition. Many politicians in the upper echelons of the Party took a reactionary stance and resisted change in any direction. The experience of the purges meant that most still feared punishment for any leeway to those opposed to Stalinist rule. See Sharon L. Wolchik, Czechoslovakia in Transition. Politics, Economics, and Society (London: Pinter Publishers, 1991), $25-6$.

44 See Jủza, 'Smutná léta padesátá', 32. 
the Prague Riding School. The mere fact that the exhibition remained open to the public signalled an important political victory, and showed that the art world had gained at least some degree of autonomy.

The growing interest in Czech avant-garde works was, indirectly, a reaction to Stalinist propaganda which continually presented Czechoslovakia in a fraternal or filial relation to the Soviet Union. As a result, it was claimed that the nations shared the same political and cultural aims, as well as identities. By the end of the I95os this image had lost the appeal it had enjoyed following the end of the Second World War. The Stalinist system had fallen short of the ideals voiced in I945. Many artists who had been fervent Communist supporters became first disillusioned, then shocked and embittered by the acts of political terror and systematic suppression of certain characteristics of Czechoslovak history, culture and art. They were equally disappointed, and ultimately bored, by the repetitive and predictable kind of art generated by the Soviet school of Socialist Realism. Reacting against this, Czech artists sought inspiration in the past, and began to identify with art historical developments which, in the context of contemporary Eastern bloc culture, were both different and yet typically $\mathrm{Czech}$. The Czech avant-garde was regarded as just such a phenomenon. By (re)claiming it as an inseparable part of Czech art history, the idea of a Soviet-free Czech culture was reinforced. ${ }^{45}$ Claiming Kupka (who had French citizenship) as a 'Czech national artist' must also be understood from this perspective.

\section{The Changing Reception of Contemporary Abstract Art}

The appearance of Cubist and Surrealist works in The Visual Arts and state galleries did not mean that political censorship had been fully relaxed. On the contrary, the works of most contemporary innovative artists who had formed unofficial art groups were still banned. Censorship was still enforced, and special employees of the Chief Press Inspection Board (Hlavní správy tiskového dohledu) continued to scrutinise art exhibition programmes, art catalogue reproductions and accompanying texts, for any 'wayward' sentiments. Anything which did not conform to the censors' directives was excised before publication. The names of certain artists were banned in publications, particularly the names of those who had emigrated to the West. ${ }^{46}$

Those artists who defined their identity by stressing present-day links between Czech and Western European artistic movements were regarded by the censors as especially dangerous. Their interest in the works and aesthetics of their Western colleagues suggested that the Iron Curtain was not shut quite as tightly as the

45 The anthropologist Ladislav Holy argued that, after 1948 , the idea of an autonomous Czech identity was not denied outright: "Hand in hand with the officially proclaimed ideology of "proletarian intemationalism" went the recognition of the national principle in the organisation of communist society and the communist state'. Ladislav Holy, 'The End of Socialism in Czechoslovakia', in C. M. Mann (ed.), Socialism: Ideals, Ideologies and Local Practice (London: Routledge, 1994), 809-10.

46 Dušan Tomášek, Pozor, cenzurováno! Aneb ze života soudruzky cenzury (Prague: MV C̆R, 1994), I I I-I 4 . 
Czechoslovak state leaders might have wished. Western-orientated Czech artists managed to keep up with recent artistic developments in the West by reading publications which were occasionally smuggled into the country. Subsequently, they attempted to incorporate what they saw into their own work. As the sculptor Hugo Demartini recalled:

When information about Western post-war abstractionism started to get through we were influenced by it, whether it be work by the painter Alberto Burri, or by George Mathieu. From time to time a magazine with those things in it made it through to Czechoslovakia. To us this influence was very welcome, because . . it gave us more possibility to develop our own work.

Some information about contemporary Western art could even be found in the official libraries which kept on their subscriptions to some Western art journals.

There was the university library and the library of the Museum of Applied Art which collected certain Western magazines about architecture and the applied arts. We, the young people, always went along and looked through them to find certain things which we were normally not allowed to see.

The producers of unofficial Western-orientated abstract art, encouraged by the increasing tolerance of The Visual Arts and rumours about de-Stalinisation in the Soviet Union, tried to have their works accepted by the official state galleries. Towards the end of the 1950 some of them succeeded in holding public exhibitions of their works. In 1957, some members of Máj $57^{47}$ held an exhibition in Obecní dưm in Prague. A year later the art critic František Śmejkal organised an exhibition in the lecture rooms of the Philosophical Faculty at Charles University, including Existentialist and abstract works. ${ }^{48}$ In the same year non-conformist works by a number of young artists were exhibited in the House of Art (Dum Uméní) in Brno. To make it politically acceptable, the exhibition was presented as an historical turning-point of a genuine approach of fresh artistic powers to generate new creative possibilities in socialist art'. ${ }^{49}$ Although the exhibition was fiercely criticised at the eleventh Congress of the Czechoslovak Communist Party, it remained open. In its own way this was a considerable victory for the proponents of artistic variety but, in the overall context of state censorship, it was relatively insignificant. Art exhibitions continued to be censored and exhibitions of non-conformist art were frequently closed. The painter Adriena Simotová, one of the members of the unofficial art group UB I2, vividly recalled how the programme of censorship continued:

I had an exhibition with the sculptress Věra Janoušková in a small exhibition hall on Karlovo náměstí in I960. In art terms it wasn't by any means revolutionary, but the work was very daring. They didn't close that exhibition. But when we had another exhibition with the group UB 12 in I96I, they closed it and re-opened it three times. They forced us to remove

47 Libor Fára, Josef Istler, Oto Janeček, A. Karášek, Jan Kotík, P. Kotík, Mikulăš Medek and Karel Teissig

${ }^{48}$ See Jan Kr̆žź, 'Imaginace-struktura-divnost', in Jiñ Vykoukal, ed., Záznam nejrozmanitějš́ch faktori. České malírství 2. poloviny 2o. stoleti ze sbírek galeni (Prague: Národní galerie, 1993), 37; Vlastimil Tetiva, Ćeské malírství a socharství 2. poloviny 20. stol, 90.

49 Vilém Jùza, 'Smutná léta padesátá', 33. 
some of the works, then re-opened it. The exhibitions were always closed for so-called technical reasons. They formed committees to judge the works, as if we were criminals.

Despite the continued censorship, non-conformist artists persisted in trying to enter the official art scene. In Scott's words, 'the hidden transcript [was] continually pressing against the limit of what [was] permitted on stage', just like 'a body of water pressing against a dam'. ${ }^{50}$

The dam finally burst in I964. After Khrushchev's second de-Stalinisation speech in $196 \mathrm{I}$, the politicians who adhered to his views put the Czechoslovak President Antonín Novotný under increasing pressure to introduce political and economic changes. ${ }^{51}$ As a result, in the field of the visual arts, hardline Stalinists quickly lost ground. Artists and art historians who defined artists as 'free creators' were able to take up influential positions in the Art Union, and introduce organisational changes. In 1964, the art historian Jindrich Chalupecký, well known for his vociferous criticism of political censorship and his ardent support of political non-conformism, was appointed Chairman of the Art Union. Together with other members of the Union, he introduced a number of measures aimed at reducing political restrictions on artists' activities. In an article in 1969 he reviewed the changes as follows:

[In 1965] the Union abolished the position of Central Secretary, and thus wrenched itself free from control by political institutions. By the beginning of 1965 the Union had reinstated all those who had been discriminated against. The Union also put an end to the censorship of exhibitions. At the same time, exhibiting abroad was permitted and all artists were eligible to receive scholarships irrespective of their [political] opinions. ${ }^{52}$

Officially, artists were re-identified as free creators, and measures were taken to guarantee the autonomy of the Czech art world in which non-political specialists would judge the quality of art. In itself, the ideal of a depoliticised art world was, of course, part of the political discourse of reformist Communist politicians such as Alexander Dubček. In the Art Union plans were made to decentralise the art world and re-introduce organisational pluralism through the establishment of independent art associations. The fate of Hungary's uprising in 1956 was similarly repeated in Czechoslovakia. The invasion by the Warsaw-pact troops in 1968 and the introduction of the programme of normalisation thwarthed the Art Union's plans. Czech artists were once again expected to take up the role of political propagandist. ${ }^{53}$

\section{Conclusion}

When the Communist Party seized power in 1948, its leaders took complete control of the exhibition and purchase of art works. Non-figurative avant-garde art was

50 Scott, Domination and the Arts of Resistance, 196.

51 See Jacques Rupnik, The Other People (London: Weidenfeld and Nicolson, 1988), I 7I-2; François Fejto, A History of the People's Democracies (New York: Penguin Books, 197I), 70.

52 Jindrich Chalupecký, 'K čemu je Svaz?', V'ýtvamá Práce, Vol. 17, no. 3-4, I I.

53 For a detailed analysis of subsequent developments in the Czech art world, see Svašek, 'Styles, Struggles, and Careers', 88-234. 
denounced and banned as the product of a hostile, 'bourgeois', international élite. Artists were redefined as political propagandists who should work in a realist manner and depict scenes which promoted Communist ideals. Prominent representatives of the Czech avant-garde art movement were no longer able to advance their careers whereas, in contrast, artists working according to the Socialist Realist principles gained artistic success and were held up as examples to the rest of the artistic community. Socialist Realist discourse was propagated in a new Communist art magazine in which art historians rewrote art history from a Communist perspective. Artists who, before 1948 , had won national and international recognition, were either classed as 'bourgeois enemies' or 'progressive friends', depending on their political views.

The art world was re-organised in such a way that public artistic discourse reinforced the authority of the Communist Party. Art students were trained to produce ideologically acceptable works, reinforcing a notion of Czech national identity which referred to folklore, lay culture and the collective fight against the international bourgeoisie. However, the Communist Party failed to halt completely the production of art works opposed to Communist discourse. A small group of artists refused to work in figurative or Socialist Realist styles and continued to take their inspiration from non-figurative avant-garde work. They rejected the Communists' optimistic political view, and defined their art content as a reflection of existentialist problems. They produced images which emphasised human suffering and experimented with abstraction. Their works were consequently banned from public exhibition and became symbols of a clandestine artistic discourse. Although the works were not allowed to be publicly exhibited, they were viewed and discussed in the privacy of artists' studios. Such works resisted the merging of Communist and artistic discourse, and implicitly challenged the authority of the Stalinist regime.

In I955, public debates were staged in which critical Art Union members (some of them respected Party members) protested against its overwhelming centralising control and its refusal to acknowledge artistic plurality. Until then, some of them had expressed their criticism in secret, afraid of being labelled as enemies of the state. The protests did not, however, lead to organisational changes. Hardline Stalinists in the Union, with the government's backing, opposed decentralisation: as a result, the unofficial groups remained just that. After 1955, however, the Communist art journal The Visual Arts began to publish articles in which critical art historians openly attacked Socialist Realism's rigidly enforced ideas, and rehabilitated artists who had produced avant-garde art during the first half of the twentieth century. Cubism and Surrealism were redefined as artistic movements which were characteristic of Czech art history, and therefore, elements of Czech culture which distinguished the Czechs from other Communist nations.

Official exhibition policy in the late I950s used a twin-track approach which fostered conflicting images of Czech artistic identity. Exhibitions of Czech avantgarde art were organised by art historians who managed, in part due to international political changes, to express their formerly hidden views on Czech art and the task 
of Czech artists in public. At the same time, the more dogmatic art historians continued to organise exhibitions of Socialist Realist works, emphasising the Communist identity of Czech art. After $196 \mathrm{I}$, as part of a wider process of deStalinisation, the Party began to exercise less control over the Union's activities, which in turn allowed more liberal artists and art historians to take up key positions. They redefined art as an autonomous discourse and promoted Western-orientated, politically non-conformist artists. Their plans to implement far-reaching decentralising reforms were, however, thwarted when they were dismissed from their influential positions as a result of political normalisation.

\section{Appendix}

Table. Percentage of works $^{1}$ by artists from Czechoslovakia, other Communist countries and the West in the art joumal V'́tvarmé Uméni (The Visual Arts)

\begin{tabular}{|c|c|c|c|c|}
\hline & Czech & East & West & Other \\
\hline 1950 & 46.5 & $43.5^{2}$ & $10^{3}$ & 0 \\
\hline I95I & 50.5 & 32.5 & I 4.5 & 2.5 \\
\hline $1952^{4}$ & - & - & - & \\
\hline 1953 & 79.7 & I $3 . I$ & $3 \cdot \mathrm{I}$ & 4. I \\
\hline 1954 & 63.9 & 25.5 & 6.6 & 4 \\
\hline 1955 & 73.9 & 8 & I I & 7.1 \\
\hline 1956 & 56.8 & 4.2 & $34.6^{5}$ & 4.4 \\
\hline 1957 & 42.3 & I9. I & 26.3 & 12.3 \\
\hline 1958 & 65.3 & 5 & $24 \cdot 3$ & 5.4 \\
\hline 1959 & 75.6 & 8.8 & 7 & 8.6 \\
\hline I 960 & 72.2 & 4.8 & I7 & 6 \\
\hline I 96 I & 71.5 & $10.6^{6}$ & I I .9 & 6 \\
\hline 1962 & 74.9 & 3 & I 8.3 & 3.8 \\
\hline I 963 & 52.3 & I. 2 & 36 & 10.5 \\
\hline 1964 & 65.1 & 0.8 & 26.5 & 7.6 \\
\hline 1965 & 64.2 & 6.4 & I 8.5 & 10.9 \\
\hline 1966 & 63.8 & 5 & 27.2 & 4 \\
\hline 1967 & 54 & $2 \mathrm{I}$ & 24 & I \\
\hline 1968 & 75.6 & 3.7 & 20.6 & 0.1 \\
\hline I969 & 62.2 & $4 \cdot 3$ & 25.4 & 8. I \\
\hline
\end{tabular}

Each volume contains between 250 and 550 photographic reproductions of art works.

Socialist Realist works mainly by Soviet artists.

3 Figurative and Socialist Realist works.

4 Unfortunately this volume was missing from the libraries of the Academy of Fine Arts and the Museum of Applied Arts in Prague.

5 Figurative and abstract works.

6 Mainly Russian abstract Modernists. 